\title{
Radiodegradation of nadolol in the solid state and identification of its radiolysis products by UHPLC-MS method
}

\author{
Magdalena Ogrodowczyk $^{1}$ - Katarzyna Dettlaff ${ }^{1} \cdot$ Waldemar Bednarski $^{2}$. \\ Barbara Ćwiertnia ${ }^{3}$ Maciej Stawny ${ }^{1}$ - Grzegorz Spólnik ${ }^{4} \cdot$ Juliusz Adamski $^{5}$. \\ Witold Danikiewicz ${ }^{4}$
}

Received: 13 February 2017/ Accepted: 30 August 2017/Published online: 9 September 2017

(C) The Author(s) 2017. This article is an open access publication

\begin{abstract}
Nadolol $\quad\left(\left(2 R^{*}, 3 S^{*}\right)-5-\left\{\left[\left(2 R^{*}\right)\right.\right.\right.$-3-(tert-butylamino)-2-hydroxypropyl]oxy $\}-1,2,3,4$ tetrahydronaphthalene-2,3-diol) in substantia was exposed to ionizing radiation generated by a beam of high-energy electrons in an accelerator, in the standard sterilisation dose of $25 \mathrm{kGy}$ and in higher doses of $50-400 \mathrm{kGy}$. The irradiated and non-irradiated (control) samples were analysed by the infrared spectrophotometry, electron paramagnetic resonance, differential scanning calorimetry (DSC) and ultrahigh performance liquid chromatography coupled with mass spectrometry (UHPLC-MS). The irradiated samples were found to contain free radicals in concentrations much higher than that observed for the other irradiated $\beta$-blockers. On the basis of UHPLC-MS results, it was possible to establish structures of 11 compounds of the impurities and/ or products of nadolol decomposition. The main product of radiodegradation was concluded to be formed as a result of abstraction of the hydroxyl group and aromatization of the tetrahydronaphthalene ring. The results of DSC measurements confirmed the presence of radiolysis products in the
\end{abstract}

Magdalena Ogrodowczyk

mogrodo@ump.edu.pl

1 Department Pharmaceutical Chemistry, Poznan University of Medical Sciences, Grunwaldzka 6, 60-780 Poznań, Poland

2 Institute of Molecular Physics, Polish Academy of Sciences, Smoluchowskiego 17, 60-179 Poznań, Poland

3 Department of Inorganic and Analytical Chemistry, Poznan University of Medical Sciences, Grunwaldzka 6, 60-780 Poznań, Poland

4 Institute of Organic Chemistry, Polish Academy of Sciences, Kasprzaka 44/52, 01-224 Warsaw, Poland

5 Institute of Forensic Research, Westerplatte 9, 31-033 Kraków, Poland irradiated samples of nadolol. A shift of the endothermic peak corresponding to melting towards lower temperatures (by $4.4{ }^{\circ} \mathrm{C}$ at the dose of $400 \mathrm{kGy}$ ) was directly proportional to the doses of radiation used, which permits concluding that this method is sensitive and suitable for evaluation of radiodegradation of nadolol in solid phase.

Keywords Nadolol $\cdot$ Radiosterilization · Free radicals . Degradation product - UHPLC-MS

\section{Introduction}

Nadolol belongs to a numerous group of pharmaceuticals blocking the $\beta$-adrenergic receptors, known as $\beta$-blockers, applied in the treatment of circulatory system. The main structural element of the majority of $\beta$-blockers is the aryloxyalkylaminopropanol group. Of particular, impact on the mechanisms of activity of this group of drugs are the substituents at the amino group, most often they are isopropyl groups of tert butyl groups-such as in nadolol, (Fig. 1). These substituents determine the degree of affinity to $\beta$-receptor of laevorotatory isomers. However, eventually the effectiveness of the drug depends on its aryl part as it controls the selectivity and activity towards adrenergic receptors. Nadolol comprises a two-ring aryl substituenttetrahydronaphthalene-which means it acts nonselectively on $\beta$-adrenergic receptors $\beta 1$ and $\beta 2$.

Nadolol is recommended for the treatment of hypertension, coronary disease and arrhythmia, moreover, according to recent studies it is also effective in the treatment of migraine and it can be safely applied against the above conditions even in the patients suffering from chronic mild asthma (Baker et al. 2011; Lopez-Sendon et al. 2004; Hanania et al. 2010). 
<smiles>CC(C)(C)NCC(O)COc1cccc2c1CC(O)C(O)C2</smiles>

Fig. 1 Structure of nadolol

The sterilization and decontamination of therapeutic drugs by exposition to ionizing radiation has been accepted by European Pharmacopoeia (European Pharmacopeia 2005) for many years. It offers a number of unquestionable advantages such as the possibility of sterilization in different forms and packages and at all temperatures, but it has a main drawback of the risk of drug deterioration by the ionizing radiation (Crucq et al. 2005). That is why it is so important to resolve the mechanism of radiodegradation of therapeutic drugs to be submitted to sterilization by irradiation (Marciniec and Dettlaff 2008).

The effect of gamma irradiation in the dose of $30 \mathrm{kGy}$ on nadolol has been studied by a Belgian group (Engalytcheff et al. 2003, 2004). For analysis of the effect, they used the electron paramagnetic resonance (EPR) to evaluate the concentration of free radicals and ultra-high performance liquid chromatography (UHPLC) to detect the radiolysis products. The level of radiodegradation was found as $<0.3 \%$ to give 1 main radiodegradation product and 12 other products in trace amounts. In comparison to the results obtained for the other seven $\beta$-blockers: acebutolol, atenolol, esmolol, labetalol, metoprolol, pindolol and propranolol, for nadolol the content of free radicals generated by irradiation was much higher; the radiation yield was $3.8 \times 10^{-8} \mathrm{~mol} / \mathrm{J}$, so on average the number of free radicals was ten times higher than in the other $\beta$ blockers.

This paper is a continuation of our studies on the effects of ionizing irradiation on therapeutic drugs from the group of $\beta$-blockers (Marciniec et al. 2010, 2011; Ogrodowczyk et al. 2013, 2014, 2015). The aim of this study was determination of radiochemical stability of nadolol by spectrophotometric, thermal and chromatographic methods and identification of the products of its radiodegradation. To detect even the smallest changes in the drug taking place upon irradiation, often the doses of irradiation applied in the studies are much higher (100-400 kGy) than the standard dose used for sterilization (25 kGy) (European Pharmacopoeia 2014; CEN 1994).

\section{Experimental}

\section{Materials}

Nadolol, abbreviated as ND, $\left(2 R^{*}, 3 S^{*}\right)-5-\left\{\left[\left(2 R^{*}\right)-3\right.\right.$-(tertbutylamino)-2-hydroxypropyl]oxy $\}-1,2,3,4$ tetrahydronaphthalene-2,3-diol, molecular formula $\mathrm{C} 17 \mathrm{H} 27 \mathrm{NO} 4$, molecular weight 309.40 , CAS number 42200-33-9. Fluka Analytical, Lot BCBB8918.

\section{Irradiation with e-beam radiation}

A few portions of approximately $0.5 \mathrm{~g}$ of nadolol were placed in separate transparent glass jars of $3 \mathrm{ml}$ volume closed with plastic stoppers. The samples were irradiated with doses of 25, 50, 100, 200, $400 \mathrm{kGy}$ of electron-beam radiation from a linear electron accelerator Elektronika $10 / 10$, the energy of electrons was $9.96 \mathrm{MeV}$ and the current intensity $6.2 \mu \mathrm{A}$.

\section{Organoleptic analysis}

The nadolol samples were examined before and after irradiation, to determine their appearance, colour, smell and clarity of the solution obtained by its dissolution in water, according to the European Pharmacopoeia (2014).

\section{Fourier transform infrared spectroscopy (FT-IR)}

$\mathrm{KBr}$ discs were prepared by mixing $1.00 \mathrm{mg}$ of nadolol with $300 \mathrm{mg}$ of $\mathrm{KBr}$ and compressing the samples obtained under a Pye Unicam minipress. The spectra were recorded using a Bruker IR spectrometer, in the range $500-4000 \mathrm{~cm}^{-1}$ with $\mathrm{KBr}$ as a blank. The apparatus was calibrated using water and its resolution was $2 \mathrm{~cm}^{-1}$.

\section{Melting point determination}

The melting points of nadolol were determined by the capillary method using MP 70 Melting Point System (Mettler Toledo). The measurements were performed for non-irradiated and irradiated nadolol samples $(25,50,100$, 200 and $400 \mathrm{kGy}$ ). The samples were heated from 25 to $139{ }^{\circ} \mathrm{C}$, in the range $124-139{ }^{\circ} \mathrm{C}$ the heating rate was $1{ }^{\circ} \mathrm{C} /$ $\min$. The result was an average of three measurements.

\section{Differential scanning calorimetry (DSC)}

Measurements were performed on an instrument DSC-50 Shimadzu, Japan. Samples of $2 \mathrm{mg}$ were sealed in aluminium crucibles with pierced lids. The samples were thermally equilibrated at $20{ }^{\circ} \mathrm{C}$ for $5 \mathrm{~min}$ and the 
measurements were performed at a heating rate of $5{ }^{\circ} \mathrm{C} /$ min in nitrogen atmosphere $(30 \mathrm{ml} / \mathrm{min})$. For each sample, three independent measurements were performed and the results were averaged.

\section{Ultra-high performance liquid chromatography coupled to mass spectrometry (UHPLC-MS)}

UHPLC/TOF-MS experiments were carried out using an Ultra-Performance Liquid Chromatograph ACQUITY UPLC I-Class (Waters Inc.) coupled with Synapt G2-S HDMS (Waters Inc) mass spectrometer equipped with an electrospray ion source and q-TOF (tandem quadrupole/time of flight)-type mass analyser. The instrument was computer controlled and recorded data were processed using the MassLynx V4.1 software package (Waters Inc).

UHPLC separations were performed using a $2.1 \times 100 \mathrm{~mm}$ BEH C18 $(1.7 \mu \mathrm{m})$ column (Waters). Solvent $\mathrm{A}$ was water with $5 \mathrm{mM}$ of $\mathrm{CH}_{3} \mathrm{COONH}_{4}$ and solvent $\mathrm{B}$ was acetonitrile. The gradient flow was used in all measurements. The gradient started with $5 \%$ of solvent B and increased to $100 \%$ of solvent $\mathrm{B}$ in $10 \mathrm{~min}$ than this condition was maintained for $3 \mathrm{~min}$ and the sample was brought back to the initial conditions. The flow rate was $0.3 \mathrm{ml} / \mathrm{min}$.

All experiments were carried out using $\mathrm{MS}^{\mathrm{E}}$ mode providing simple spectra and the fragmentation spectra without ion pre-selection for every compound in the sample. Nitrogen was used as the nebulizer and cone gases. The tip voltage was kept at $3000 \mathrm{~V}$. The cone voltage was set to $22 \mathrm{~V}$. The collision energy (CE) for high-energy spectra was ramped from 20 to $40 \mathrm{eV}$. The resolving power FWHM (Full Width at Half Maximum) of the TOF analyser was 38000 .

\section{EPR spectroscopy}

Continuous-wave $\mathrm{X}$-band $(9.4 \mathrm{GHz})$ electron paramagnetic resonance measurements were performed on a Bruker ELEXSYS E500 spectrometer with SuperX ER49X Microwave Bridge equipped with Super High Sensitivity Probehead (Bruker BioSpin GmbH, Rheinstetten, Germany). Magnetic field measurements were achieved by an NMT-Teslameter ER 036TM (Bruker BioSpin GmbH, Rheinstetten, Germany). All EPR experiments were performed at $295 \mathrm{~K}$. Spin concentration was calculated after double integration of EPR spectra according to the procedure described elsewhere (Mai et al. 2013).

\section{Calculation of radiation yield}

Radiation yield is defined as the number of the degraded molecules of the reactant or the number of molecules of newly formed products to the amount of energy absorbed by the system. Radiation yield of nadolol free radicals $\left(G_{\mathrm{FR}}\right)$ is defined as the ratio of free radicals formed as a result of irradiation with the energy of $100 \mathrm{eV}$ :

$G_{\mathrm{FR}}=\frac{x}{100 \mathrm{ev}}$,

$x$ number of molecules formed as a result of irradiation with energy of $100 \mathrm{eV}$.

$1 \mathrm{kGy}=1000 \mathrm{~Gy} ; \quad 1 \mathrm{~Gy}=100 \mathrm{rad} ; \quad 1 \mathrm{rad}=6.243$ $\times 10^{13} \mathrm{eV} / \mathrm{g}$

Radiation yield can be also expressed in the SI units as $\mathrm{mol} / \mathrm{J}$.

\section{Results and discussion}

As recommended by the European Pharmacopoeia, the studies were begun with organoleptic examination. The ionizing radiation in the doses used did not generate changes in the form and smell of the drug. However, already after irradiation with the dose of $25 \mathrm{kGy}$, the colour of the sample changed from white to pale cream and after irradiation with higher doses (up to $4000 \mathrm{kGy}$ ) the colour changed into deeper cream. Organoleptic examination indicated that nadolol was sensitive to ionizing radiation and the colour change observed can be a consequence of formation of a colour product or products of radiolysis.

To verify this hypothesis the samples were subjected to melting point measurements by the capillary method and to differential scanning calorimetry (DSC) analysis. It is known that the presence of impurities including decomposition products and also radiodegradation products, causes a decrease in the melting point of a given drug. The melting point of non-irradiated nadolol sample was in the range $129.5-135.9^{\circ} \mathrm{C}$ (Table 1) which is in agreement with literature values $124-136{ }^{\circ} \mathrm{C}$ (Moffat et al. 2011).

The DSC curve of non-irradiated nadolol showed one sharp endothermic peak at $133{ }^{\circ} \mathrm{C}\left(T_{\max }\right)$. In the curves recorded for the samples irradiated with increasing doses this peak was shifted towards lower temperatures in a proportional manner (Fig. 2). The linear relations between $T_{\text {onset }}$ and $T_{\max }$ and the dose of irradiation are described by the correlation coefficients $r=0.9610$ and $r=0.9234$, respectively. The enthalpy of melting varied in the range $0.11-0.14 \mathrm{~kJ} / \mathrm{g}$ (Table 1$)$.

At the next stage of the study, the samples were subjected to infrared spectrophotometric analysis. The FT-IR spectra of non-irradiated nadolol and the sample irradiated with $400 \mathrm{kGy}$ (16 times the standard dose) are in full agreement and the intensity of bands at particular wavenumbers does not change (Fig. 3). This result indicates that the structure of the samples did not change and 
Table 1 Thermal analysis data obtained by means of DSC and capillary method

\begin{tabular}{llllllll}
\hline Radiation dose (kGy) & \multicolumn{2}{l}{ Capillary method } & & \multicolumn{1}{l}{ DSC method } \\
\cline { 2 - 3 } & $T_{\text {onset }}\left({ }^{\circ} \mathrm{C}\right)$ & $T_{\text {endset }}\left({ }^{\circ} \mathrm{C}\right)$ & & $T_{\text {onset }}\left({ }^{\circ} \mathrm{C}\right)$ & $T_{\max }\left({ }^{\circ} \mathrm{C}\right)$ & $T_{\text {endset }}\left({ }^{\circ} \mathrm{C}\right)$ & $\Delta H(\mathrm{~kJ} / \mathrm{g})$ \\
\hline 0 & 129.5 & 135.9 & & 129.2 & 133.0 & 139.7 & -0.14 \\
25 & 129.0 & 135.0 & & 129.0 & 133.3 & 138.6 & -0.14 \\
50 & 129.0 & 133.5 & & 127.9 & 132.0 & 138.2 & -0.12 \\
100 & 128.3 & 129.0 & & 127.5 & 131.6 & 137.7 & -0.12 \\
200 & 127.3 & 128.0 & & 126.6 & 131.0 & 137.1 & -0.11 \\
400 & 126.5 & 134.5 & & 125.3 & 130.1 & 136.6 & -0.13 \\
\hline
\end{tabular}

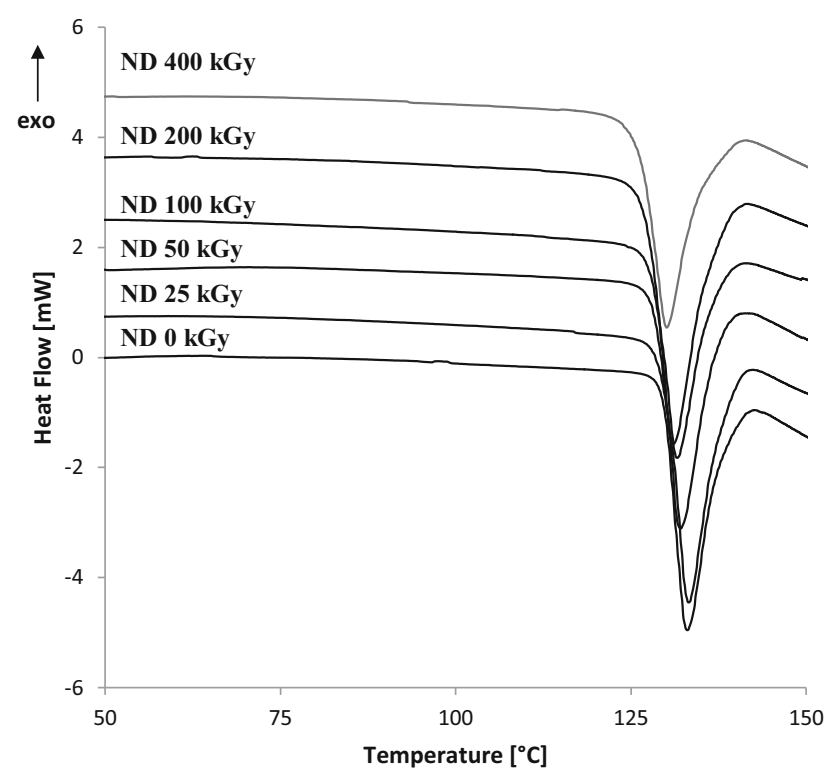

Fig. 2 The DSC curves of nadolol before and after irradiation

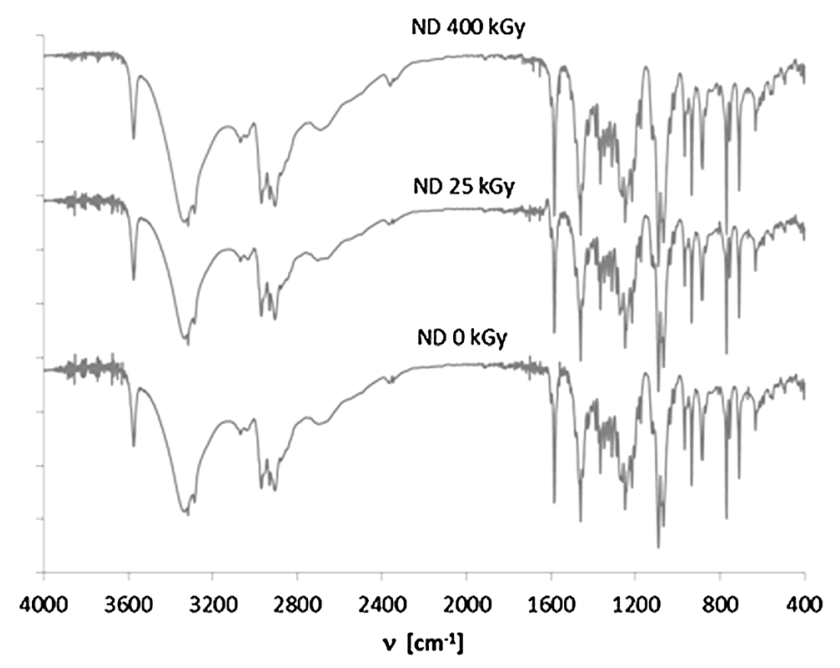

Fig. 3 FT-IR spectra of nadolol before and after irradiation

the products of radiodegradation occur in small amounts and their structures are probably similar to the parent compound. The identification of radiodegradation products and estimation of their amounts required chromatographic analysis coupled with mass spectrometry.

The liquid chromatography analysis revealed the appearance of one major impurity and several minor ones as a result of irradiation (Fig. 4).

The dehydration followed by the oxidation of second hydroxyl group to ketone and subsequent tautomerisation leading to the aromatization of the ring led to the formation of the main degradation product whose structure comprises that of naphthol (Fig. 5). This major impurity could be easily found in samples irradiated with the dose of $25 \mathrm{kGy}$. Other degradation products (Table 2.) were identified in the samples irradiated with the dose of $400 \mathrm{kGy}$.

The amount of the major impurity $(\mathrm{H})$ was 0.3 and $2 \%$ in the samples irradiated with 25 and $400 \mathrm{kGy}$, respectively [these values were estimated as the respective peak area to the peak area corresponding to the main compound at a concentration of $0.2 \%$ to the nominal concentration $(100 \%)]$. Several structures for the minor impurities were proposed. They were mainly products of oxidation or dehydration processes of the nadolol molecule, and included also positional isomer of the major impurity (Fig. 5.).

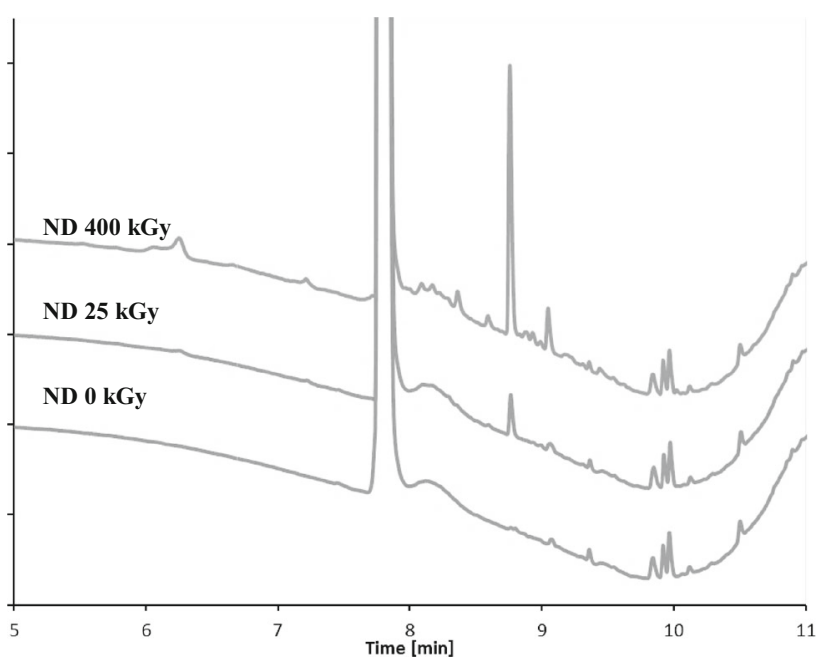

Fig. 4 UHPLC-UV chromatograms of nadolol before (blue line) and after irradiation (25 kGy red line, $400 \mathrm{kGy}$ green line) 


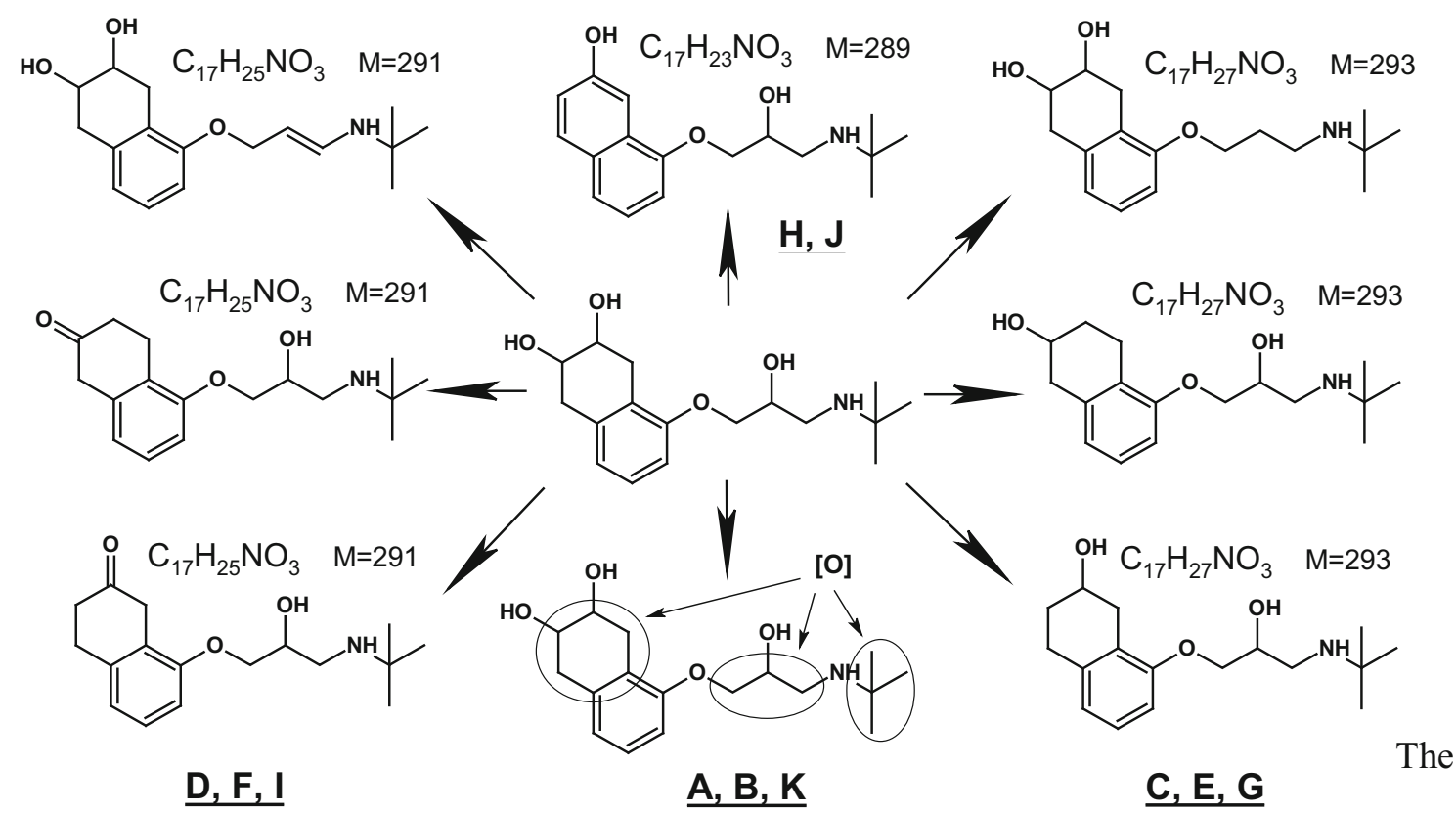

Fig. 5 The degradation paths of nadolol

Table 2 Impurities identified in the nadolol samples

\begin{tabular}{llllccc}
\hline Symbol & $\begin{array}{l}\text { Retention time } \\
(\mathrm{min})\end{array}$ & $\begin{array}{l}\text { Measured mass }[\mathrm{M}+\mathrm{H}] \\
(\mathrm{m} / z)\end{array}$ & $\begin{array}{l}\text { Theoretical mass }[\mathrm{M}+\mathrm{H}] \\
(\mathrm{m} / z)\end{array}$ & $\begin{array}{l}\text { Mass error } \\
(\mathrm{mDa})\end{array}$ & $\begin{array}{l}\text { Molecular } \\
\text { formula }\end{array}$ & $\begin{array}{l}\text { Molecular mass } \\
(\mathrm{Da})\end{array}$ \\
\hline A & 7.22 & 324.1810 & 324.1811 & -0.1 & $\mathrm{C}_{17} \mathrm{H}_{25} \mathrm{NO}_{5}$ & 323 \\
B & 7.71 & 326.2001 & 326.1967 & 2.0 & $\mathrm{C}_{17} \mathrm{H}_{27} \mathrm{NO}_{5}$ & 325 \\
ND & 7.78 & 310.2018 & 310.2018 & 0.0 & $\mathrm{C}_{17} \mathrm{H}_{27} \mathrm{NO}_{4}$ & 309 \\
C & 8.09 & 294.2099 & 294.2069 & 3.0 & $\mathrm{C}_{17} \mathrm{H}_{27} \mathrm{NO}_{3}$ & 293 \\
D & 8.36 & 292.1943 & 292.1913 & 3.0 & $\mathrm{C}_{17} \mathrm{H}_{25} \mathrm{NO}_{3}$ & 291 \\
E & 8.36 & 294.2103 & 294.2069 & 3.4 & $\mathrm{C}_{17} \mathrm{H}_{27} \mathrm{NO}_{3}$ & 293 \\
F & 8.59 & 292.1910 & 292.1913 & -0.3 & $\mathrm{C}_{17} \mathrm{H}_{25} \mathrm{NO}_{3}$ & 291 \\
G & 8.71 & 294.2080 & 294.2069 & 1.1 & $\mathrm{C}_{17} \mathrm{H}_{27} \mathrm{NO}_{3}$ & 293 \\
H & 8.76 & 290.1793 & 290.1788 & 0.5 & $\mathrm{C}_{17} \mathrm{H}_{24} \mathrm{NO}_{3}$ & 289 \\
I & 8.84 & 292.1947 & 292.1913 & 3.4 & $\mathrm{C}_{17} \mathrm{H}_{25} \mathrm{NO}_{3}$ & 291 \\
J & 9.05 & 290.1792 & 290.1788 & 0.4 & $\mathrm{C}_{17} \mathrm{H}_{24} \mathrm{NO}_{3}$ & 289 \\
K & 9.05 & 326.2010 & 326.1981 & 4.3 & $\mathrm{C}_{17} \mathrm{H}_{27} \mathrm{NO}_{5}$ & 325 \\
\hline
\end{tabular}

${ }^{\mathrm{a}}$ Nonionized form

The ESI-MS spectrum of the major impurity $(\mathrm{RT}=8.76 \mathrm{~min}$.) revealed a protonated ion $\mathrm{m} / \mathrm{z} 290$. The accurate mass measurement $(290.1755 \mathrm{Da})$ indicated that the elemental composition of the protonated molecule was $\mathrm{C}_{17} \mathrm{H}_{24} \mathrm{NO}_{3}$. Under the same experimental conditions, nadolol produced the protonated ion $\mathrm{m} / \mathrm{z} 310.2021$ with the elemental composition $\mathrm{C}_{17} \mathrm{H}_{28} \mathrm{NO}_{4}$-Fig. 6 .

During the fragmentation process of the $\mathrm{m} / \mathrm{z} 290$ ion (Fig. 7), iso-butene, ammonia and one hydroxyl group (instead of two observed in the nadolol fragmentation) were lost, which led to the most intense ion $\mathrm{m} / \mathrm{z}$ 199.0751 instead of $\mathrm{m} / \mathrm{z} 201.0917$ observed for nadolol (Fig. 8). This suggested a significant structural similarity between the structures of the impurity and nadolol. The most informative to the structure elucidation of the major degradation product appeared to be the $m / z, 161.0599$ ion with elemental composition $\mathrm{C}_{10} \mathrm{H}_{9} \mathrm{O}_{2}$. This ion was not present in the fragmentation spectrum of nadolol and the only structure fitting such a composition, which can be derived from the structure similar to nadolol, seemed to be the protonated dihydroxynaphthalene moiety. Most probably the naphthol structure cannot be formed in the fragmentation 
Fig. 6 The CID fragmentation spectra of nadolol (a) and impurity $\mathrm{H}$ (b)
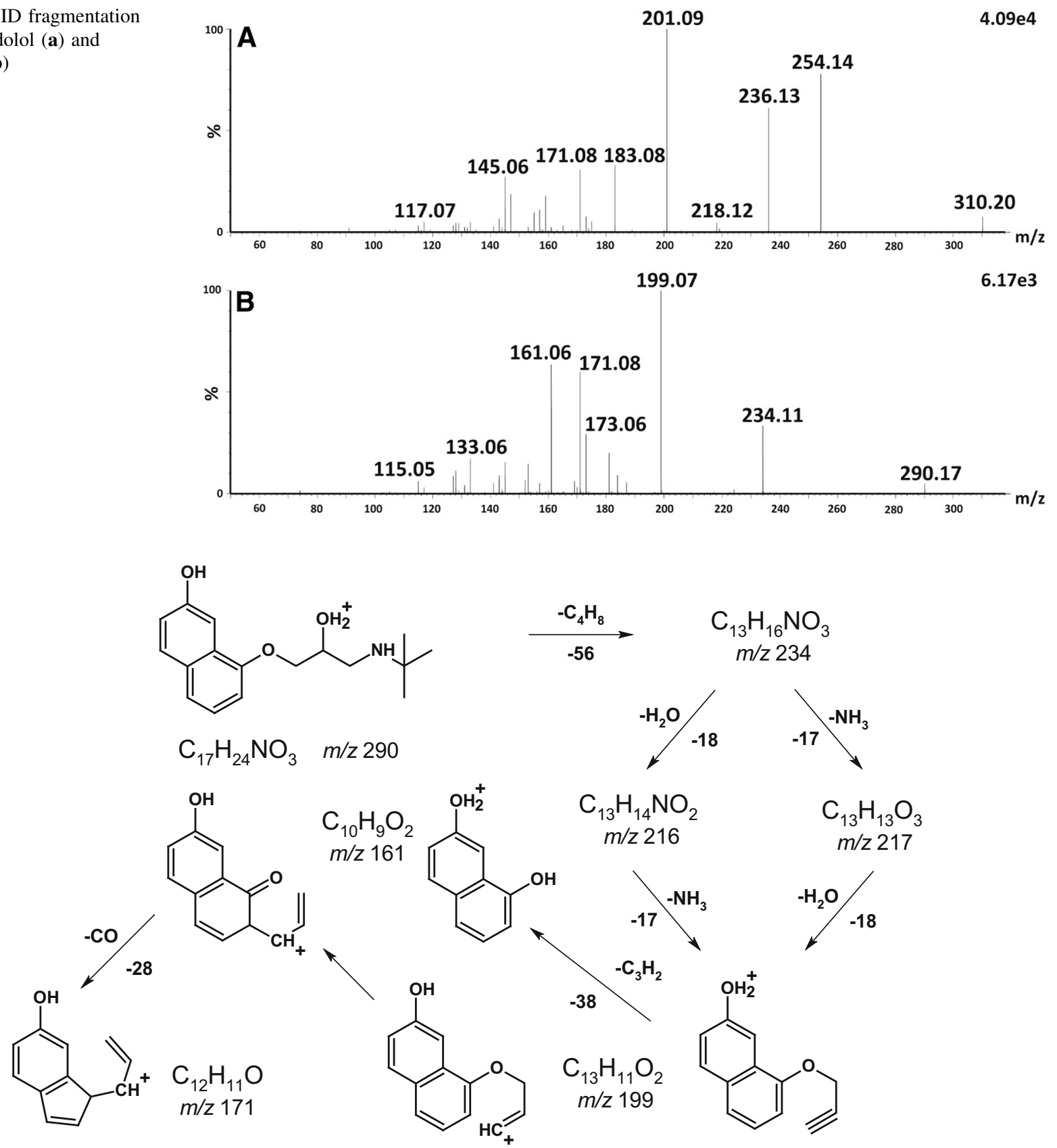

Fig. 7 The fragmentation path of the impurity H-protonated molecule

process but was present in the structure from the very beginning.

The EPR signal of non-irradiated nadolol is beyond the level of the spectrometer sensitivity, so $<0.1 \mathrm{ppm}$. The shape of EPR spectra of irradiated samples was found not to depend on the dose of irradiation and each spectrum indicates the presence of two types of radicals (Fig. 9a). The spectra show a broad intensive line L1 (26 Gs) characterised by $g$ factor of $g=2.0043( \pm 0.0007)$ of inseparable hyperfine structure, and two weak lines L2 characterised by $g$ factor values of $g=2.0261$ and 1.9810 , most probably coming from partly separated hyperfine structure. With increasing time after irradiation (Fig. 9b), lines L2 disappear and line L1 develops increasingly distinct lines assigned to hyperfine structure.

Time changes in the number of free radicals in the samples of irradiated nadolol are illustrated in Fig. 10 by a mono-exponential function:

$C(t)=C_{f}+C_{0} e^{\frac{-t}{T_{0}}}$

$T_{1 / 2}=\ln (2) T_{0}$, 
<smiles>CC(C)(C)NC[C@H]([OH2+])COc1cccc2c1CC(O)C(O)C2</smiles>

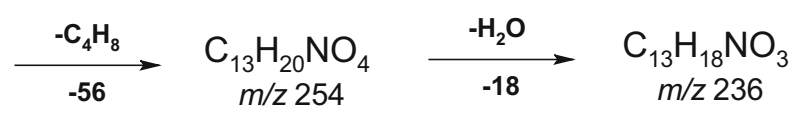

$$
\mathrm{C}_{17} \mathrm{H}_{28} \mathrm{NO}_{4} \quad \mathrm{~m} / \mathrm{z} 310
$$<smiles>C=C[C@H](C)C1C=Cc2ccccc2C1=O</smiles>

$\mathrm{m} / \mathrm{z} 155$<smiles>C=C[CH+]C1C=Cc2ccccc21</smiles>

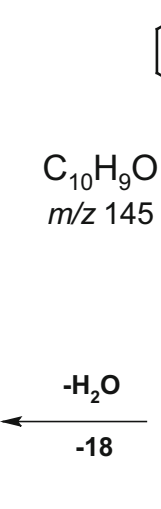<smiles>[CH2+]=CCOc1cccc2c1CC(O)C=C2</smiles>

$\mathrm{C}_{13} \mathrm{H}_{16} \mathrm{NO}_{2}$

$\mathrm{m} / \mathrm{z} 218$

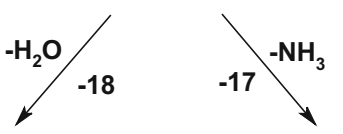

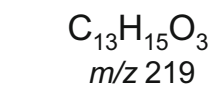

Fig. 8 The fragmentation path of nadolol-protonated molecule
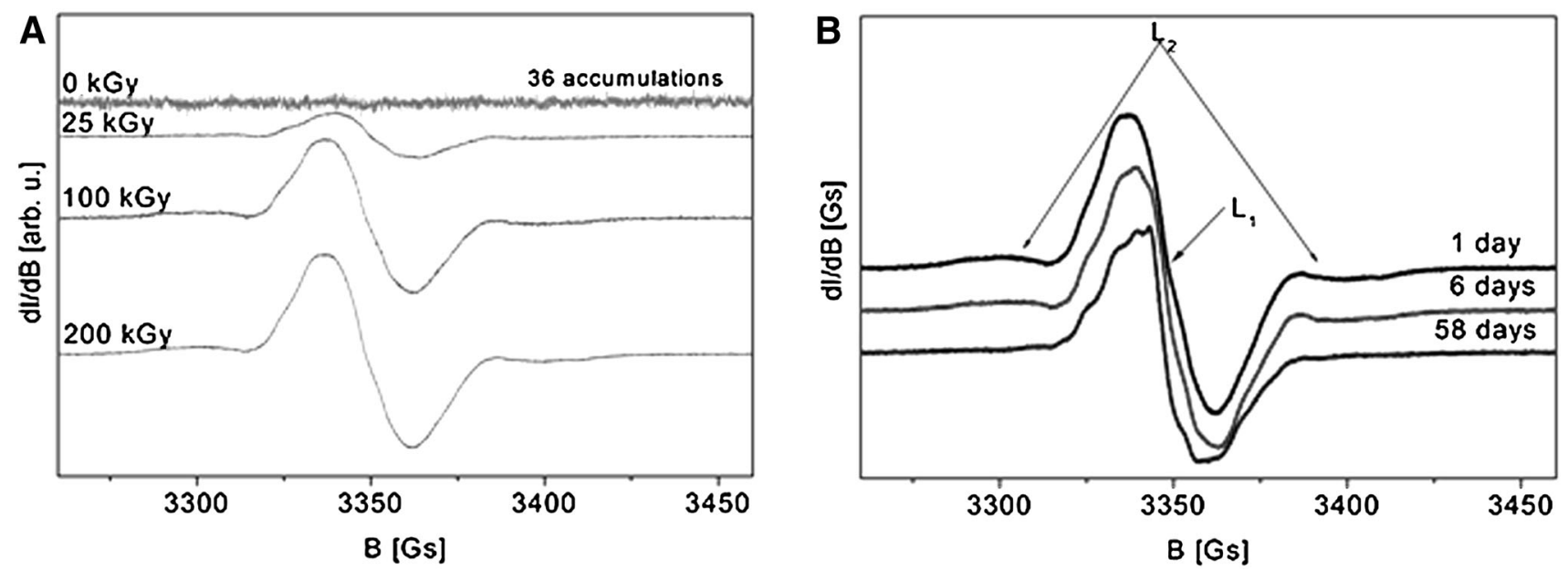

Fig. 9 The EPR signal for nadolol: a non-irradiated and irradiated ( $24 \mathrm{~h}$ after irradiation); b. irradiated with the dose of $200 \mathrm{kGy}$ versus time

where $C(t)$ is the concentration of radicals at time $t, C_{f}$ the concentration of stable (not undergoing recombination) radicals, $C_{0}$ the concentration of unstable radicals at time $t=0$ (immediately after irradiation), $T_{0}$ the mean lifetime of unstable radicals, $T_{1 / 2}$ the half-lifetime of unstable radicals (undergoing recombination).

Nadolol irradiated with the dose of $25 \mathrm{kGy}$ does not contain unstable free radicals or they disappear in the time shorter than $24 \mathrm{~h}$ after irradiation. However, it contains the stable radicals in the concentration of $71.2 \mathrm{ppm}-$ Fig. 10 . The samples irradiated with doses of 100 and $200 \mathrm{kGy}$ contain stable radicals in the concentration about three times greater than in the sample irradiated with $25 \mathrm{kGy}$ and the unstable free radicals. The number of free radicals increases with increasing dose of irradiation but not in directly proportional manner. The lifetime of unstable free radicals in the sample irradiated with $200 \mathrm{kGy}$ is $252 \mathrm{~h}$ and in the sample irradiated with $100 \mathrm{kGy}$ it is $102 \mathrm{~h}$.

The radiation yield $G_{F R}$, defined as the ratio of the number of free radicals formed as a result of exposure to ionizing radiation of the energy $100 \mathrm{eV}$ to the energy absorbed by the system, that can be expressed in $\mathrm{mol} / \mathrm{J}$, was calculated. The radiation yield GFR determined for the samples irradiated with the doses 25,100 and $200 \mathrm{kGy}$ was $8.88 \times 10^{-2}, 9.45 \times 10^{-2}$ and $5.55 \times 10^{-2} \mathrm{spin} / 100 \mathrm{eV}$ (or in $\mathrm{mol} / \mathrm{J}$ : $9.2 \times 10^{-9}, 9.8 \times 10^{-9}$ and $5.8 \times 10^{-9}$ ), 


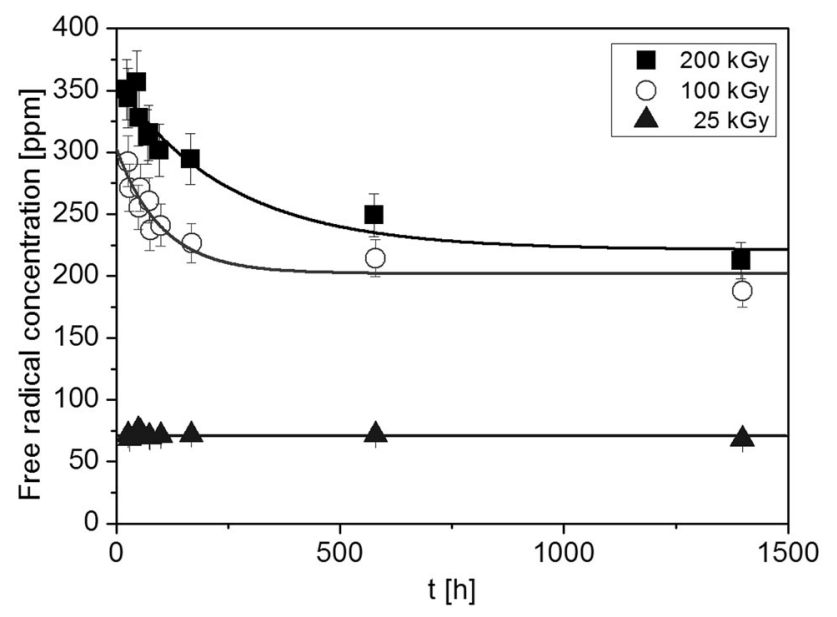

Fig. 10 The decay of free radicals in the irradiated nadolol

respectively. The yield of free radical formation was the highest for the sample irradiated with $100 \mathrm{kGy}$, slightly lower for $25 \mathrm{kGy}$, while irradiation with the dose of $200 \mathrm{kGy}$ led to the formation of a greater number of free radicals but the yield of this process was by almost $37-41 \%$ lower than that in the samples irradiated with 25 or $100 \mathrm{kGy}$. The GFR values obtained in our experiment made 14-25\% (depending on the dose) of the radiation yield obtained in the experiment reported by Engalytcheff et al. (2003), which can be explained by different conditions of the process and a different source of irradiation. Comparison of the concentrations of free radicals formed in the same conditions (irradiated with radiation generated by a beam of electrons in the dose of $25 \mathrm{kGy}$ ) in nadolol and other $\beta$-blockers, has shown that in nadolol the amount of free radicals is much higher, (Fig. 11), that is about 10 times more than in pindolol and atenolol, 24-50 times more than in propranolol, metoprolol and acebutolol and 240 times more than in atenololol (Ogrodowczyk et al. 2013, 2014; Marciniec et al. 2008). Most probably, this significant difference is related to the presence of two additional hydroxyl groups in tetrahydronaphthalene.

\section{Conclusions}

As a result of irradiation of nadolol in solid phase with e-beam radiation in the standard sterilization dose of 25 kGy (European Pharmacopoeia 2014; CEN 1994) its content decreases by about $0.3 \%$. The reduction in nadolol content is directly proportional to the shift of the melting point. As follows from the results of our study, the DSC method can be used for a fast evaluation of radiodegradation of the compound at a level of $1-2 \%$.

Another consequence of e-beam irradiation of nadolol is generation of free radicals in the concentration of

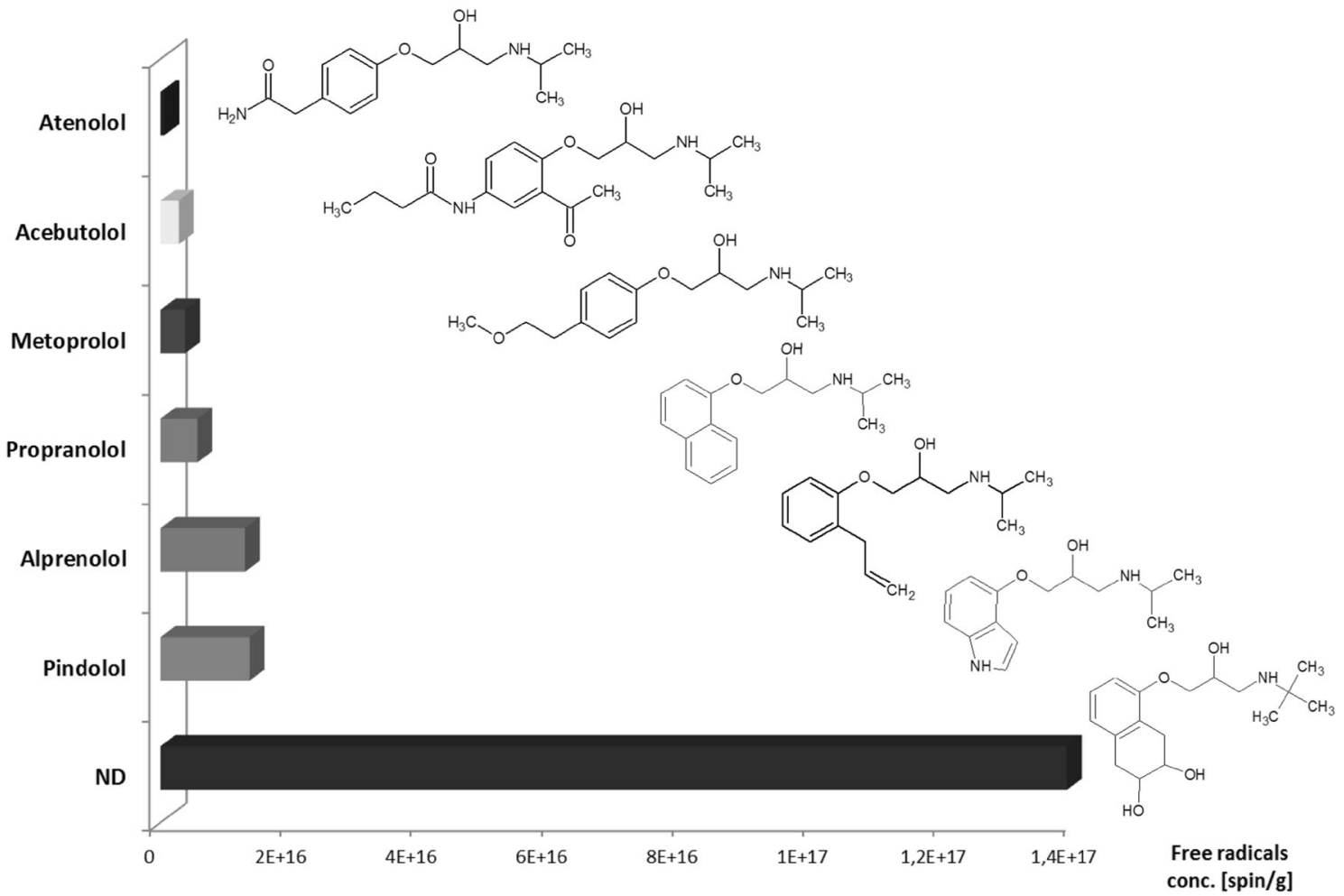

Fig. 11 The concentration of free radicals in nadolol and other $\beta$-blockers after irradiation (dose 25 kGy, e-beam) (Ogrodowczyk et al. 2013, 2014; Marciniec et al. 2008) 
$71.2 \mathrm{ppm}$, which is from 10 to 240 times more than their concentration observed for the other $\beta$-blockers subjected to sterilization in the same conditions. Most probably this very significant difference is related to the presence of two hydroxyl groups in the tetrahydronaphthalene ring. The same element of nadolol structure is involved in the main pathway of its radiodegradation, as the main product of radiodegradation is obtained by elimination of one of the $\mathrm{OH}$ groups from the tetrahydronaphthalene ring and aromatization of the ring (dehydration and dehydrogenation). The other radiolysis products are formed in trace amounts by dehydration and oxidation. The content of the main product of radiolysis which is an impurity undefined by the Pharmacopoeia (European Pharmacopoeia 2014) and a change in the colour of nadolol as a result of irradiation imply that the method of sterilisation with the standard dose cannot be applied to this drug.

Open Access This article is distributed under the terms of the Creative Commons Attribution 4.0 International License (http://crea tivecommons.org/licenses/by/4.0/), which permits unrestricted use, distribution, and reproduction in any medium, provided you give appropriate credit to the original author(s) and the source, provide a link to the Creative Commons license, and indicate if changes were made.

\section{References}

Baker JG, Hill SJ, Summers RJ (2011) Evolution of b-blockers: from anti-anginal drugs to ligand-directed signaling. Trends Pharmacol Sci 32:227-234. doi:10.1016/j.tips.2011.02.010

CEN (1994) EN 552. Sterilization of medical devices—validation and routine control of sterilization by irradiation. European Committee for Standardization, Rue de Strassart 36, B-1050, Belgium

Crucq AS, Deridder V, Tilquin B (2005) Radiostability of pharmaceuticals under different irradiation conditions. Radiat Phys Chem 72:355-361. doi:10.1016/j.radphyschem.2004.02.006

Engalytcheff A, Deridder V, Debuyst R, Tilquin B (2003) Determination of radical yields in solid-state drugs as one technique to identify drugs that will withstand radiosterilization: radioresistance of beta blockers. Radiat Res 160:103-109. doi:10.1667/ RR3020

Engalytcheff A, Vanhelleputte JP, Tilquin B (2004) HPLC detection and quantification of radiolytic products of eight beta-blockers irradiated in the solid state and hypotheses on their origins. Pharm Res 21:1103-1108. doi:10.1023/B:PHAM.0000032995. 57881.79

European Pharmacopoeia (2005) 5.1.1. Methods of preparation of sterile products, 5th edn. p 445, Strasbourg, France

European Pharmacopoeia (2014) 5.1.1. Methods of preparation of sterile products, 8th edn. p 555-556, Council of Europe, Strasbourg, France

Hanania NA, Mannava B, Franklin AE, Lipworth BJ, Williamson PA, Garner WJ, Dickey BF, Bond RA (2010) Response to salbutamol in patients with mild asthma treated with nadolol. Eur Respir J 36:963-965. doi:10.1183/09031936.00003210

Lopez-Sendon J, Swedberg K, McMurray J, Tamargo J, Maggioni AP, Dargie H, Tendera M, Waagstein F, Kjekshus J, Lechat P, Torp-Pedersen Ch (2004) Expert consensus document on b-adrenergic receptor blockers. Eur Heart J 25:1341-1362. doi:10.1016/j.ehj.2004.06.002

Mai VC, Bednarski W, Borowiak-Sobkowiak B, Wilkaniec B, Samardakiewicz S, Morkunas I (2013) Oxidative stress in pea seedling leaves in response to Acyrthosiphon pisum infestation. Phytochem 93:49-62. doi:10.1016/j.phytochem.2013.02.011

Marciniec B, Dettlaff K (2008) Radiation sterilization of drugs. Trends in radiation sterilization. IAEA, Vienna, pp 187-230

Marciniec B, Krzyminiewski R, Hofman M, Ogrodowczyk M (2008) Wykorzystanie metod EPR i DSC w badaniach niektórych $\beta$ blokerów sterylizowanych radiacyjnie $w$ fazie stałej [Application of EPR and DSC methods in analysis of some $\beta$-blockers radiosterilized in the solid phase] In: Ogólnopolskie Sympozjum Naukowe "Ocena jakości preparatów farmaceutycznych z uwzględnieniem metod badania w fazie stałej”. Book of Abstracts p. 35. Medical University of Gdańsk

Marciniec B, Ogrodowczyk M, Kwiecien A (2010) The effect of radiation sterilization on alprenolol in the solid state studied by HPTLC. J AOAC Int 93:792-797. doi:10.5740/jaoacint.14-096

Marciniec B, Ogrodowczyk M, Czajka B, Hofman M (2011) The influence of radiation sterilization on $\beta$-blockers in the solid state. Thermochim Acta 514:10-15. doi:10.1016/j.tca.2010.11.024

Moffat AC, Jacson JV, Moss MS, Widdop B (2011) Clarke's analysis of drugs and poisons. The Pharmaceutical Press, London

Ogrodowczyk M, Marciniec B, Czwajda A (2013) The effect of ionizing radiation on metoprolol. Drug Dev Ind Pharm 39:1005-1009. doi:10.3109/03639045.2012.692379

Ogrodowczyk M, Marciniec B, Kachlicki P (2014) Spectroscopic analysis of pindolol irradiated in the solid state. Cent Eur J Chem 12:60-66. doi:10.2478/s11532-013-0348-7

Ogrodowczyk M, Dettlaff K, Kachlicki P, Marciniec B (2015) Identification of radiodegradation products of acebutolol and alprenolol by HPLC-MS-MS method. J AOAC Int 98:46-50. doi:10.5740/jaoacint.14-096 